\title{
Corrigendum
}

\section{Corrigendum to "Prediction of Concrete Compressive Strength and Slump by Machine Learning Methods"}

\author{
M. Timur Cihan (iD \\ Civil Engineering, Tekirdă̆ Namık Kemal University, Çorlu Faculty of Engineering, Tekirdă̆ 59860, Turkey \\ Correspondence should be addressed to M. Timur Cihan; mehmetcihan@nku.edu.tr \\ Received 20 July 2020; Accepted 20 July 2020; Published 30 August 2020 \\ Copyright (C) 2020 M. Timur Cihan. This is an open access article distributed under the Creative Commons Attribution License, \\ which permits unrestricted use, distribution, and reproduction in any medium, provided the original work is properly cited.
}

In the article titled "Prediction of Concrete Compressive Strength and Slump by Machine Learning Methods" [1], there was an error in equation (1), which should be corrected as follows:

$$
\text { MAE }=\frac{1}{n} \sum_{i=1}^{N} \mid \text { predicted }_{i}-\operatorname{actual}_{i} \mid .
$$

\section{References}

[1] M. Timur Cihan, "Prediction of concrete compressive strength and slump by machine learning methods," Advances in Civil Engineering, vol. 2019, p. 11, Article ID 3069046, 2019. 